\title{
natureouTLook
}

\section{THE SPINE}

14 November 2013 / Vol 503 / Issue No 7475

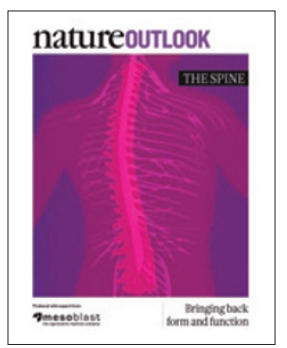

Cover art: Andrew Baker

Editorial

Herb Brody, Mike May,

Michelle Grayson, Tony

Scully, Rachel Jones,

Nick Haines

Art \& Design

Wes Fernandes,

Mohamed Ashour,

Amr Rahma,

Lucy Verey

Production

Karl Smart, Susan

Gray, lan Pope, Leonora

Dawson-Bowling

Sponsorship

Will Piper, Yvette Smith,

Reya Silao

Marketing

Elena Woodstock,

Steven Hurst

Project Managers

Christian Manco,

\section{Art Director}

Kelly Buckheit Krause

Publisher

Richard Hughes

Magazine Editor

Rosie Mestel

Editor-in-Chief

Philip Campbell
E very year up to a quarter of a million people around the world suffer a spinal-cord injury. These devastating injuries can end lives, rob people of their mobility and burden healthcare systems. As this Outlook shows, advances in medicine and technology are offering new ways to reduce pain and restore mobility.

Researchers are developing a variety of approaches to repairing spinal injuries. Some techniques use stem cells or reprogram existing cells to help the body recreate neurons damaged in an injury (page S4). Regenerative techniques are already helping to mend vertebrae, and replacement discs are being developed that closely mimic their natural components (S7). New drugs can treat pain, improve the level of recovery after an injury, and possibly stimulate biological mechanisms to replace damaged cells (S10). And biomechanical engineer Peter Cripton shows how collecting neck-injury data can trigger ideas for designing better safety devices, such as helmets that protect the head and neck (S13). A growing body of data shows that the consequences of such an injury depend critically on the emergency treatment provided, including medications that limit the damage (S14). If medical action is not enough, the latest technologies could help. Mechanical systems called exoskeletons can help a paraplegic to stand, walk and even climb stairs (S16).

For spine injuries, as with all healthcare, prevention is better than cure. Rehabilitation and prevention specialist Sara Klaas argues that safer behaviour, from avoiding multitasking when driving to eliminating trip hazards, can reduce the chances of an injury and save billions of dollars (S18). Ultimately, a combination of treatments from immediately after an injury to decades beyond can turn a devastated patient into a productive one with a fulfilling life.

We acknowledge the financial support of Mesoblast in producing this Outlook. As always, Nature has full responsibility for all editorial content.

Mike May

Contributing Editor
Nature Outlooks are sponsored supplements that aim to stimulate interest and debate around a subject of interest to the sponsor, while satisfying the editorial values of Nature and our readers' expectations. The boundaries of sponsor involvement are clearly delineated in the Nature Outlook Editorial guidelines available at http://www. nature.com/advertising/resources/pdf/outlook_guidelines.pdf CITING THE OUTLOOK

Cite as a supplement to Nature, for example, Nature Vol XXX, No. XXXX Suppl, Sxx-Sxx (2013). To cite previously published articles from the collection, please use the original citation, which can be found at the start of each article.

VISIT THE OUTLOOK ONLINE

The Nature Outlook Spine supplement can be found at http://www. nature.com/nature/outlook/spine/
All featured articles will be freely available for 6 months. SUBSCRIPTIONS AND CUSTOMER SERVICES For UK/Europe (excluding Japan):Nature Publishing Group Subscriptions, Brunel Road, Basingstoke, Hants, RG21 6XS, UK. Tel: +44 (0) 1256 329242. Subscriptions and customer services for Americas - including Canada, Latin America and the Caribbean: Nature Publishing Group, 75 Varick St, 9th floor, New York, NY 10013-1917, USA. Tel: +1 8663637860 (US/Canada) or +1 212726 9223 (outside US/Canada). Japan/China/Korea:Nature Publishing Group - Asia-Pacific, Chiyoda Building 5-6th Floor 2-37 Ichigaya Tamachi, Shinjuku-ku, Tokyo, 162-0843, Japan. Tel: +81 33267875 CUSTOMER SERVICES

Feedback@nature.com

Copyright $\odot 2013$ Nature Publishing Group

\section{CONTENTS}

S2 PHYSIOLOGY

Sensation and loss

Charting the body's nerve centre

S4 STEM CELLS

A time to heal

Testing a transformative treatment

S7 REGENERATIVE MEDICINE

Rebuilding the backbone

Researchers grow replacement parts

S10 DRUG DEVELOPMENT

Chemical brace

Coaxing neurons to reconnect

S13 PERSPECTIVE

Protecting the neck

Let technology take the brunt of the force, says Peter Cripton

S14 EMERGENCY MEDICINE

The need for speed

Immediate care is critical to the patient

S16 TECHNOLOGY

Mobility machines

Robotic exoskeletons take first steps

S18 PERSPECTIVE

Avoiding injury

Wise up to hazards and avoid accidental injury, says Sara Klaas

\section{COLLECTION}

S19 Missed pediatric spinal injuries neurological consequences? Volker Dietz

S21 Light touch and pin prick disparity in the International Standard for Neurological Classification of Spinal Cord Injury (ISNCSCI)

$N$ Vasquez, A Gall, P H Ellaway \& M D Craggs

\$25 The translational dialogue in spinal cord injury research

A Curt

S31 Three-dimensional imaging of the unsectioned adult spinal cord to assess axon regeneration and glial responses after injury Ali Ertük etal.

S37 Intraspinal AAV injections immediately rostral to a thoracic spinal cord injury site efficiently transduces neurons in spinal cord and brain

Michelle C Klaw, Chen Xu \& Veronica J Tom 